\title{
Pengaruh Motivasi Kerja Terhadap Kinerja Karyawan Dengan Kepuasan Kerja Sebagai Variabel Moderasi
}

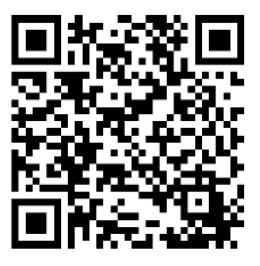

\author{
Abdul Majid ${ }^{*}$ Adi Lukman Hakim ${ }^{2^{*}}$ Elvina Assadam ${ }^{3^{*}}$ \\ DOl: https://doi.org/10.36339/jaspt.v5i1.396
}

\begin{abstract}
Abstrak
Penelitian ini bertujuan untuk mendeskripsikan motivasi kerja, kepuasan kerja dan kinerja karyawan serta menganalisis kepuasan kerja dalam memoderasi pengaruh motivasi kerja terhadap kinerja karyawan. Metode penelitian ini dengan pendekatan kualiatif dan kuantatif. Populasi penelitian ini seluruh karyawan Hotel Pardise Batu, sehingga pengambilan sampelnya menggunakan teknik total sampling. Deskriptif data dan regresi moderasi digunakan sebagai analisis data. Hasil menunjukan bahwa motivasi kerja berpengaruh terhadap kinerja karyawan, motivasi kerja, kepuasan kerja dan interaksi antara motivasi kerja dan kepuasan kerja berpangaruh positif dan signifikan terhadak kinerja karyawan, dan kepuasan kerja memoderasi pengaruh motivasi kerja dan kinerja karyawan
\end{abstract}

Kata Kunci: motivasi kerja, kinerja karyawan, kepuasan kerja

\section{Abstract}

This study aims to describe work motivation, job satisfaction and employee performance and to analyze job satisfaction in moderating the effect of work motivation on employee performance. This research method with qualitative and quantative approaches. The population of this study were all employees of Hotel Pardise Batu, so that the sampling used total sampling technique. Descriptive data and moderated regression were used as data analysis. The results show that work motivation has an effect on employee performance, job motivation, job satisfaction and the interaction between work motivation and job satisfaction has a positive and significant effect on employee performance, and job satisfaction moderates the effect of work motivation and employee performance

Keywords: work motivation, employess performance , job satisfaction

\section{PENDAHULUAN}

Peningkatan kinerja merupakan suatu hal yang diinginkan baik dari perusahaan maupun semua pekerja. Pemberi kerja menginginkan kinerja karyawannya baik untuk kepentingan peningkatan hasil kerja dan keuntungan perusahaan. Di sisi lain, para pekerja berkepentingan untuk pengembangan diri dari promosi pekerjaan. Banyak sekali faktor yang dapat mempengaruhi kinerja karyawan atau pegawai. Faktor-faktor yang mempengaruhi kinerja menurut Mathis \& Jackson (2006) yaitu kemampuan, motivasi, dukungan atau dorongan yang diterima, keberadaan pekerjaan yang dilakukan dan hubungan dengan organisasai atau perusahaaan.

The research was financed by Kemenristekdikti. No. 2017A171(Sponsoring information)

Email of Corresponding Author majidumla1@gmail.com Universitas Muhammadiyah Lamongan

2. Program Studi Manajemen Universitas Muhammadiyah Lamongan

3. Program Studi Manajemen Universitas Muhammadiyah Lamongan Jalan Raya Plalangan Plosowahyu KM 3 Lamongan, Jawa Timur 
Bangun (2012) juga menyebutkan bahwa kinerja pegawai merupakan tingkat pencapaian dari hasil kerja seseorang berdasarkan persyaratan pekerjaan atau standar kerja yang merupakan tingkat yang diharapkan suatu pekerjaan tertentu untuk dapat diselesaikan dan terus diperbandingkan atas tujuan atau target yang ingin dicapai. Di sisi lain, para pekerja yang berkepentingan untuk pengembangan pada diri dari promosi pekerjaan. Bamyak faktor yang dapat mempengaruhi kinerja karyawan atau pegawai. Beberapa Faktor-faktor yang mempengaruhi kinerja menurut Mathis \& Jackson (2006) yaitu kemampuan, motivasi, dukungan atau dorongan yang diterima, keberadaan pekerjaan yang dilakukan serta adanya suatu hubugan dengan organisasai atau perusahaan.

Menjalankan perusahaan pada perhotelan dituntut untuk terus untuk melakukan pembenahan berbagai aspek terutama dibidang SDM. Salah satu perusahaan yang berbentuk pelayanan hotel adalah Hotel Paradise yang beralamat di Jalan Diponegoro 06 Kota Batu. Perusahaan ini didirikan pada tahun 2010 dengan lokasi strategis yaitu di jalan utama menuju kota Batu dimana menjadi lokasi yang tepat untuk singgah dan bermalam. Hotel Batu Paradise memiliki kamar dengan jumlah 60 kamar dan karyawan dengan jumlah 45 orang. Hotel Batu Paradise membagi kelas kamarnya dalam 5 kelas yaitu juna, Superiuor, Exclusive, Royal dan Deluxe. Karyawan pada hotel ini juga terbagi dalam beberapa departemen yaitu house keeping department, food and beverage, dan front office department.

Berdasarkan yang dilakukan oleh peneliti dengan menggunakan metode wawancara kepada HRD Hotel Paradise Batu diperoleh informasi bahwa terdapat indikasi penurunan kinerja karyawan Batu paradise pada tiga bulan terakhir di awal tahun 2019 yaitu pada bulan januari, februari dan maret. Kinerja karyawan dilihat mengalami penurunan yang terus meningkat dari bulan januari, februari dan maret yang dibuktikan dengan tingkat komplain konsumen kepada Hotel yang tinggi pada bulan januari dan meningkat hingga ke bulan februari. Indikasi penurunan kinerja karyawan juga dibuktikan ketidaktepatan pada waktu penyelesaian pekerjaan oleh karyawan. Masih terdapat beberapa karyawan yang merasa kesulitan untuk mengatasi seluruh keinginan dari tamu-tamu serta untuk dapat menyelesaikan pekerjaan tepat waktu. Sehingga adanya fenomena ini perlu dilakukan evaluasi terhadap kinerja perusahaan.

Meningkatnya kinerja selain dipengaruhi oleh motivasi juga dipengaruhi oleh tingkat kepuasan dari karyawan, karena kepuasan dengan supervisi juga mempunyai korelasi signifikan dengan motivasi dimana seorang manajer memberi perlakuan dan memberikan motivasi pekerja melalui berbagi usaha meningkatkan kepuasan kerja. Kepuasan kerja merupakan akan respons affective atau emosional di berbagai segi pekerjaan seseorang (Kreitner \& Kinicky, 2010). Kepuasan kerja karyawan dapat dilihat melalui rasa adil dan layak balas jasa yang diterima pekerja (kompensasi), penempatan pekerjaan yang sesuai dengan keahlian pekerjaan, suasana dan lingkungan pekerjaaan, sifat pemimpin dan sifat pekerjaaan yang monoton.

Kajian secara imperis penelitian yang berkaitan dengan penelitian ini diantara Irwansyah (2019) menjelaskan bahwa kepuasan kerja dapat memoderasi pengaruh motivasi kerja terhadap kinerja karyawan. Penelitian oleh Devi dan Sulistywati (2018) juga menjelaskan

JAS-PT

JURNAL ANALISIS SISTEM PENDIDIKAN TINGGI ISSN $2580-5339$ eISSN $2620-5718$ Volume 5 Nomor 1 JULI 2021 Hal 9 - 16 kepuasan kerja menjadi penengah dalam suatu meningkatkan dari kinerja perusahaan, tidak hanya itu saja penelitian yang dilakukan oleh Nadhiroh (2019) yang menyimpulkan bahwa suatu perusahaan kinerjanya meningkat maka perlu untuk meningkatkan motivasi kerja perusahaan, tidak hanya motivasi kerja melainkan kepuasan kerja menjadi pemoderasi dalam meningkatkan performance perusahaan. Riskayani (2017) menyalurkan hasil penelitiannya bahwa kepuasan kerja dapat memediasi kinerja karyawan. 


\section{Pengembangan Hipotesis}

Menurut Robbins \& Judge (2013) motivasi merupakan keinginan untuk melakukan sesuatu dan menentukan kemampuan bertindak untuk memuaskan suatu kebutuhan individu. Dengan segala kebutuhan tersebut, seseorang dituntut untuk bekerja lebih giat dan aktif dalam bekerja, karena dengan adany seseorang memiliki motivasi yang tinggi lebih dalam melakukan pekerjaannya maka kinerja seseorang didalam perusahaan akan meningkat dan target perusahaan dapat tercapai.

Penelitian ini relevan dengan hasil penelitian oleh Ali et al (2016) menyebutkan salah satu faktor yang mempengaruhi kinerja karyawan yaitu faktor motivasi, dimana motivasi merupakan kondisi yang menggerakan seseorang berusaha untuk mencapai tujuan atau mencapai hasil yang diinginkan. Hasil penelitian ini selaras dengan penelitian Josep (2015); Ghaffari \& Nazri (2017); Sandhu et al (2017); Kuswati (2020); Ghaffari et al (2020)yang menunjukan bahwa motivasi menjadi pemicu kinerja perusahaan yang semakin meningkat. Artinya kinerja perusahaan akan semakin meningkat karena adanya motivasi dari dalam perusahaan. Sehingga Hipotesis yang dapat diajukan pada penelitian ini: $\mathrm{H1}$ : Motivasi memiliki pengaruh yang signifikan terhadap kinerja

Hasil penelitian yang dilakukan Noermijiti \& Primasari (2015); dan Palar (2016) bahwa dengan hasil motivasi dan kepuasan yang memberikan pengaruh signifikan terhadap peningkatan kinerja perusahaan. Hasil penelitian oleh Adam \& Kamase (2019) Kepuasan kerja berpengaruh positif dan signifikan terhadap kinerja karyawan. Kompetensi berpengaruh positif dan tidak signifikan terhadap kinerja karyawan melalui kepuasan kerja. Kemudian motivasi yang signifikan dan pengaruh positif terhadap kinerja yang dimediasi oleh pekerjaan kepuasan. Hasil penelitin ini relevan dengan penelitian oleh Aryanta et al (2019) yang memaparkan juga hasilnya yang menunjukkan bahwa motivasi dan kepuasan memberikan pengaruh positif dan signifikat terhadap kinerja. H2: Motvasi dan kepuasan memiliki pengaruh yang signifikan terhadap kinerja

Menurut Wibowo (2015) motivasi memiliki hubugan yang signifikan terhadap kinerja dengan kepuasan sebagai korelasi, karena kepuasan dengan supervisi juga mempunyai korelasi signifikan dengan motivasi. Terjadinya kepuasan kerja disebabkan oleh adanya kinerja atau prestasi kerja sehingga pekerja yang lebih produktif akan mendapatkan kepuasan kerja. Hasil penelitian yang dilakukan oleh Ardiaza \& Noemijati (2017); Otto (2018) memaparkan bahwa kepuasan kerja memberikan pengaruh antara motivasi terhadap kinerja perusahaan. Hasil penelitian relevan dengan penelitian oleh hasil AlMusadieq et al (2018) menerangkan bahwa kinerja perusahaan semakin meningkat difaktori adanya kepuasan kerja yang menjadi pendorong sebuah perusahaan untuk meningkat. Dengan demikian, kepuasan memberikan pengaruh positif pada kinerja perusahaan. Maka hipotesinya yang dapat diajukan adalah. H3: Kepuasan memoderasi pengaruh motivasi terhadap kinerja.

\section{METODE PENELITIAN}

Penelitian ini merupakan jenis penelitian survei, dimana langsung terjung kelapangan untuk melihat secara langsung dan kemudian dilakukan pendistribusian kuesioner untuk melakukan pengumpulan data yang dibutuhkan peneliti. Sehingga sampel pada penelitian ini semua karyawan Hotel Paradise Batu sebanyak 45 responden. Sebelum dilakukan uji data, dilakukan pengujian instrument dengan memberikan kuesioner kepada karyawan sebanyak 25 orang.

Pengukuran pada penelitian ini dengan menggunakan skala likert dengan memberikan kuesioner yang ada pilihan lima alternativ mulai dari sengat setuju hingga sangat tidak

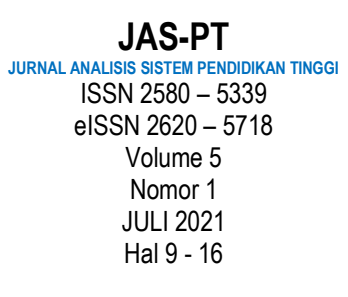

DOSEN INDONESIA SEMESTA 
setuju. Teknik yang digunakan pada penelitian ini dengan menggunakan deskriptif statistik untuk mendeskripsikan dilapangan dengan data yang diperloleh dan menggunakan moderasi regresi analisis dengan aplikasi khusus dimana dalam persamaan regresi yang mengandung unsur interaksi perkalian dua atau lebih variabel independent.

\section{HASIL DAN PEMBAHASAN}

\section{Deskriptif Statistik}

Hasil deskriptif statistik tentang motivasi kerja di Hotel Paradise secara Batu Keseluruhan analisi deskriptif statistik pada variabel motivasi kerja memiliki nilai rata-rata 158,75 , yang termasuk kategori tinggi. Hal ini dapat diartikan bahwa motivasi kerja di hotel termasuk tinggi, karena didasarkan pada tinggi dorongan atas pemberian gaji/upah, keselamatan kerja dan perlindungan kerja, hubungan dengan atasan langsung, dan pengembangan potensi kepada karyawan. Motivasi yang tinggi mendorong karyawan bekerja lebih baik.

Hasil kajian penelitian deskriptif statistik secara keseluruhan pada variabel kepuasan kerja mencapai nilai rata-rata 143,2. Skor tersebut mencerminkan kriteria perolehan cukup, Kondisi ini menunjukkan bahwa karyawan meras cukup puas dengan pekerjaan yang dilakukan. Artinya, karyawan cukup puas atas gaji atau komponen finansial lain yang diberikan, cukup puas dengan adanya kesempatan promosi, cukup puas dengan hubungan sosial dengan rekan kerja yang terjalin di hotel, cukup puas dengan pekerjaan yang dilakukan, dan cukup puas dengan hubungan dengan atasan.

Selanjutnya hasil deskriptif statistik pada kinerja karyawan, nilai yang diperoleh adalah 99,67 dan tergolong kategori rendah. Hal ini dikarenakan nilai tersebut berkisar antara 81-116. Artinya, kinerja karyawan pada ketiga departemen, yaitu departemen front office, house keeping, dan food and beverage, adalah rendah. Rendahnya kinerja ditunjukkan dengan keterlambatan menyelesaikan pekerjaan, ketidaksesuaian kualitas kerja, dan ketidakmampuan karyawan dalam mencapai kuantitas yang telah ditetapkan oleh hotel dalam melayani tamu.

\section{Moderasi Regresi Analisis}

Analisis regresi moderasi (moderated regression analysis) digunakan untuk mengetahui pengaruh variabel independen terhadap variabel dependen dengan variabel moderasi. Pada penelitian ini dengan pengujian dilakukan untuk menganalisis pengaruh motivasi kerja terhadap kinerja karyawan dengan kepuasan kerja sebagai variabel moderasi. Variabel moderasi dalam penelitian merupakan interaksi antara variabel motivasi kerja dan kepuasan kerja yang berperan sebagai variabel independen. Adapun hasil dari pengujian tersebut yaitu:

Tabel 1. Hasil Uji Moderasi Regresi Ananlsis

\begin{tabular}{lccc}
\multicolumn{1}{c}{ Variabel } & Koefisien Regresi & thitung & Sig \\
\hline Motivasi Kerja $(\mathrm{X})$ & 1,823 & 8,414 & 0,000 \\
Kepuasan Kerja $(\mathrm{Z})$ & 0,827 & 3,680 & 0,001 \\
$(\mathrm{X})^{*}(\mathrm{Z})$ & 0,074 & 5,451 & 0,000 \\
\hline Konstanta & & 10,256 & \\
Adjusted $R$ Square $\left(\mathrm{R}^{2}\right)$ & & 0,683 & \\
Determinasi $\mathrm{R}^{2}$ & & 0,714 &
\end{tabular}

Sumber: Data Primier diolah 
Angka determinasi $R$ yang diperoleh pada penelitian ini adalah 0,714 . Artinya, $71,4 \%$ variabel kinerja karyawan dijelaskan oleh variabel motivasi kerja, kepuasan kerja, dan interaksi antara motivasi kerja dan kepuasan kerja, sisanya yaitu $28,6 \%$ dijelaskan oleh variabel selain variabel dalam penelitian ini.

Nilai pada determinasi $\mathrm{R}$ mengartikan koefisien determinasi atau peranan hubungan variabel independen dengan variabel dependen. Pada tabel 4.12, nilai R2 adalah 50,7\% sementara pada tabel 4.13 , nilai tersebut mencapai $71,4 \%$. Kenaikan prosentasi tersebut menunjukkan bahwa penambahan variabel moderasi berguna untuk memperkuat persamaan hubungan motivasi kerja dan kepuasan kerja tarhadap kinerja karyawan. Hal tersebut didasarkan pada adanya kenaikan prosentase nilai determinasi R2 sebesar $20,7 \%$ setelah variabel moderasi dimasukkan dalam persamaan. Sehingga, dapat dijelaskan bahwa variabel kepuasan kerja merupakan pemoderasi dalam hubungan antara motivasi kerja dan kinerja karyawan

\section{SIMPULAN DAN SARAN}

Motivasi kerja merupakan cara pemimpin dalam mempengaruhi perilaku anggotanya untuk dapat bekerja sama dalam menyelesaikan pekerjaan secara lebih produktif demi mencapai tujuan organisasi atau instansi (Hasibuan, 2016). berdasarkan hasil analisis rentang skala, motivasi kerja yang diberikan oleh hotel batu paradise adalah tinggi, motivasi yang tinggi ini selanjutnya dapat mendorong karyawan untuk menunjukkan semangat kerja yang baik, indikator penilaian motivasi kerja dibatasi atas kebutuhan eksistensi, kebutuhan untuk menjalin hubungan, kebutuhan pertumbuhan.

Kepuasan kerja karyawan merupakan reaksi emosional atau sudut pandang karyawan atas pekerjaan yang dilakukan. berdasarkan hasil analisis rentang skala, kepuasan kerja di hotel batu paradise berada pada kategori cukup. artinya bahwa selama ini karyawan merasa cukup puas terhadap gaji yang diberikan, kesempatan promosi yang ditawarkan, rekan kerja yang kooperatif, dan perasaan tentang pekerjaan.

Kondisi ini menunjukkan bahwa ekspektasi karyawan terhadap pekerjaan yang dilakukan dengan pelaksaannya cukup sesuai, karena perusahaan cenderung mampu memenuhi keinginan karyawan untuk mendorong karyawan dalam menyelesaikan pekerjaan. Hal ini juga serupa dengan teori yang disampaikan oleh (Sutrisno, 2016), yang menyebutkan bahwa kepuasan kerja muncul karena adanya harapan yang diinginkan dan realitas yang dirasakan oleh karyawan.

Hasil analisis rentang skala, karyawan mengungkapkan hasil rentang skala yang rendah. hal ini berarti bahwa karyawan sering terlambat dalam menyelesaikan pekerjaan. Karyawan bagian front office memiliki kinerja yang rendah pada pemberian pelayanan, dimana mereka melayani lebih dari 10 menit per tamu. serupa dengan karyawan bagian front office, karyawan bagian house keeping juga menunjukkan performa kerja yang rendah pada pembersihan ruangan. mengacu pada standar kerja, seharusnya pekerjaan membersihkan kamar diharuskan selesai sebelum 20 menit, akan tetapi hal ini tidak dilakukan sesuai dengan standar yang telah ditetapkan.

Hasil serupa juga dijelaskan pada latar belakang, dimana pengunjung hotel menyampaikan keluhan kepada bagian front office terkait keterlambatan pembersihan kamar. Selanjutnya, ketidakefektifan waktu juga ditunjukkan oleh karyawan bagian food and beverage, karyawan dibagian ini sering terlambat menyajikan makanan. Kondisi ini juga mendukung yang dijelaskan pada latar belakang.

Hasil analisis uji t pada pengujian regresi linier sederhana diketahui bahwa motivasi kerja berpengaruh signifikan terhadap kinerja karyawan. disamping itu, nilai yang dihasilkan

JAS-PT

JURNAL ANALISIS SISTEM PENDIDIKAN TINGGI

ISSN $2580-5339$

elSSN $2620-5718$

Volume 5

Nomor 1

JULI 2021

Hal 9 - 16

DOSEN INDONESIA SEMESTA 
pada pengujian tersebut adalah positif, terdapat hubungan positif antara motivasi kerja dan kinerja karyawan, dan hubungan positif ini mengungkapkan semakin tinggi motivasi kerja yang dipraktikkan di hotel batu paradise, maka kinerja karyawan juga akan semakin tinggi.

Hasil penelitian ini serupa dengan penelitian yang dilakukan oleh Josep (2015) yang berdasarkan hasil temuannya menyimpulka bahwa motivasi kerja berpengaruh positif dan signifikan terhadap kinerja karyawan. kemampuan instansi dalam mempraktikkan motivasi kerja mampu memonitor perilaku karyawan secara mandiri, imbasnya yaitu karyawan secara suka rela akan menunjukkan performa kerja yang baik.

Hasil uji analisis regresi linier berganda menunjukkan bahwa secara serentak dan parsial variabel motivasi kerja dan kepuasan kerja berpengaruh siginifikan terhadap kinerja karyawan di hotel batu paradise. uji secara simultan ditunjukkan pada hasil uji $\mathrm{F}$ dan secara parsial ditunjukkan pada uji t. Peningkatan motivasi kerja dan kepuasan kerja juga akan diikuti oleh peningkatan kinerja karyawan. hasil penelitian ini didukung dengan hasil penelitian yang dikemukakan oleh Noermijiti \& Primasari (2015); Palar (2016); dan Adam \& Kamase (2019), yang mengungkapkan bahwa secara serentak variabel motivasi kerja dan kepuasan kerja berpengaruh positif dan signifikan terhadap kinerja karyawan.

Berdasarkan uji moderasi yang dihasilkan dari analisis regresi moderasi (moderated regression analysis) menunjukkan bahwa kepuasan kerja memoderasi pengaruh motivasi kerja terhadap kinerja karyawan. variabel moderasi (interaksi antara variabel motivasi kerja dan kepuasan kerja) meningkatkan sebesar 20,7\% dari prosentase hubungan motivasi kerja, kepuasan kerja dan kinerja karyawan. analisis regresi linier berganda menunjukkan prosentase sebesar 50,7\%, sedangkan ketika sesudah ditambahkan dengan variabel moderasi, prosentase meningkatkan menjadi 70,4\%.

Hasil penelitian ini menunjukkan adanya pengaruh positif dan signfikan dari variabel kepuasan kerja pada pengaruh motivasi kerja terhadap kinerja karyawan di hotel paradise batu. artinya, kepausan kerja bersifat memperkuat hubungan motivasi kerja pada kinerja karyawan. jika interaksi antara motivasi kerja dan kepuasan kerja semakin tinggi, maka kinerja karyawan juaga akan ikut serta semakin meningkat. hasil penelitian ini juga mendukung penelitian yang dilakukan oleh Ardiaza \& Noemijiti (2017); Otto (2018); dan Al-Musadieq (2018),

\section{Rekomendasi}

Berdasarkan hasil penelitian dan pembahasan yang telah dilakukan untuk mengetahui pengaruh motivasi kerja terhadap kinerja karyawan dengan kepuasan kerja sebagai variabel moderasi di Hotel Paradise Batu, maka dapat ditarik kesimpulan sebagai berikut.

Pertama hasil daripada analisis deskriptif statistik menunjukkan bahwa motivasi kerja di Hotel Paradise Batu tersebut termasuk dalam kategori tinggi, kepuasan kerja di Hotel Paradise Batu tersebut termasuk dalam kategori cukup, dan kinerja karyawan di Hotel Paradise Batu tersebut termasuk dalam kategori rendah.

Kedua hasil dari moderasi menunjukkan bahwa Motivasi kerja berpengaruh secara parsial terhadap kinerja karyawan di Hotel Paradise Batu, motivasi kerja dan kepuasan

JAS-PT

JURNAL ANALISIS SISTEM PENDIDIKAN TINGGI

ISSN $2580-5339$

eISSN $2620-5718$

Volume 5

Nomor 1

JULI 2021

Hal 9 - 16 kerja berpengaruh secara simultan dan parsial terhadap kinerja karyawan di Hotel Paradise Batu, motivasi kerja, kepuasan kerja, dan interaksi antara motivasi kerja dan kepuasan kerja, secara serentak dan parsial berpengaruh terhadap kinerja karyawan di Hotel Paradise Batu, dan kepuasan kerja memoderasi pengaruh motivasi kerja dan kinerja karyawan di Hotel Paradise Batu 


\section{DAFTAR PUSTAKA}

Adam, F \& Kamase, J. (2019). The Effect Competence and Motivation to Satisfaction and Performance. International Journal of Scientific \& Technology Researh, 8(3), 132140.

Al-Musadieq, R, M., Solimun, K., Fernandes, S. A. R., \& A. (2018). The mediating effect of Work Motivation on the Influence of Job Design and Organizational Culture Against HR Performance. Journal of Management Development., 37(6), 452-469. https://doi.org/https://10.1108/jmd-07-20170239

Ali, A., Bin, L. Z., Piang, H. J., \& Ali, Z. (2016). The Impact of Motivastion on The Employee Performace and Job Satisfactio in IT Park (Software House) Sector of Peshawar, Pakistan. International Journal of Academic Research in Business and Social Sciences., 6(9), 297-310.

Amyar, F., Hidayah, N. N., Lowe, A., \& Woods, M. (2019). Investigating the backstage of audit engagements: the paradox of team diversity. Accounting, Auditing \& Accountability Journal.

Ardiaz, F., Sudiro, A., \& N. (2017). Pengaruh Motivasi Kerja dan Gaya Kepemimpinan Transformasional terhadap Kinerja Karyawan Dimediasi Kepuasan Kerja (Studi pada PT Bank Rakyat Indonesia (Persero) Tbk Kantor Cabang Malang Marthadinata). Jurnal Bisnis Dan Manajemen, 4(1), 10-23.

Aryanta, I, K., Setiari, N, W., \& Yasa, P, N, S. (2019). Influence of Motivation on Job Stress, Job Satisfaction and Job Performance at Alam Puri Villa Art Museum and Resort Denpasar. Jurnal Ekonomi Dan Bisnis Jagaditha, 6(2), 113-120. https://doi.org/https://doi.org/10.22225/jj.6.2.1353.113-120

Bangun, W. (2012). Manajemen Sumber Daya Manusia. Jakarta: Erlangga.

Devi, P.S.C \& Sulistyawati, E. (2018). Peran Customer Satisfaction Memediasi Pengaruh Online Trust terhadap Repurchase Intention pada Customer Florist Online di Kota Denpasar. E-Jurnal Manajemen Unud, 7(6), 2856-2886. https://doi.org/https://doi.org/10.24843/EJMUNUD.2018.v7.i06.p1

Ghaffari, S., Burgoyne, J. \& Nazri, M. (2017). The Influence of Motivation on Job Performance: A Case Study at Universiti the Influence of Motivation on Job Performance: A Case Study at Universiti Teknologi Malaysia, Australian. Journal of Basic and Applied Sciences., 11(4), 92-99.

Ghaffari, S., Shah, I. Mad., \& John, B. J. R. S. (2020). The Influence of Motivation on Job Performance: A Case Study at Universiti Teknologi Malaysia the Influence of Motivation on Job Performance: Universiti Teknologi Malaysia A Case Study at Australian. Journal of Basic and Applied Sciences., 11(4), 92-99.

Hasibuan, M. S. P. (2016). Manajemen Sumber Daya Manusia (Edisi Revi). Jakarta: PT. Bumi Aksara.

Irwansyah. (2019). Pengaruh Kepuasan Kerja dalam Memoderasi Motivasi Kerja dan Penggajian Menurut Perspektif Islam terhadap Kinerja Karyawan PT. BNI Syariah Cabang Makassar. Jurnal Ekonomi, Manajemen, Dan Akuntansi (Assets), 9(1), 4965. https://doi.org/https://doi.org/10.24252/.v9i1.10127

Joseph, O, B. (2015). The effect of employees' motivation on organizational performance. Journal of Public Administration and Policy Research., 7(4), 62-75. https://doi.org/https://doi.org/10.5897/JPAPR2014.0300

Kreitner, R., \& Kinicky, A. (2010). Organizational Behaviour. New York: McGraw-Hill.

JAS-PT

JURNAL ANALISIS SISTEM PENDIDIKAN TINGGI ISSN $2580-5339$ eISSN $2620-5718$

Volume 5

Nomor 1

JULI 2021

Hal 9 - 16

DOSEN INDONESIA SEMESTA 
Kuswati, Y. (2020). The Effect of Motivation on Employee Performance. Budapest International Research and Critics Institute-Journal (BIRCl-Journal), 3(2), 995-1002. https://doi.org/https://doi.org/10.33258/birci.v3i2.928

Mathis, L. R, \& Jackson, H. J. (2006). Human Resource Management. Ja: Salemba Empat.

Mulyana, M. (2012). Consumer Behaviour: Sukses Dengan Memahami Konsumen.

Nadhiroh, U. (2019). Pengaruh Motivasi dan Kepuasan Kerja terhadap Kinerja Karyawan dengan Budaya Organisasi Sebagai Variabel Moderating pada Koperta Langgeng Mulyo Ngancar Kediri. Develop, 3(1), 61-77. https://doi.org/10.25139/dev.v3i1.1531

Neva, S., \& Amyar, F. (2021). Pengaruh Fraud Diamond dan Gonetheory Terhadap Academic Fraud. JAS-PT (Jurnal Analisis Sistem Pendidikan Tinggi Indonesia), 5(1), 41-50.

Noermijiti \& Primasari. (2015). The Effect of Job Stress and Job Motivation on Employees' Performance Through Job Satisfaction (A study at PT. Jasa Marga (Persero) Tbk. Surabaya - Gempol branch). Journal of Economics Business and Accountancy Ventura, 18(2), 231-240.

Otto. (2018). Moderating Effect of Organizational Citizenship Behavior on the Effect of Organizational Commitment, Transformational Leadership and Work Motivation on Employee Performance. International Journal of Law and Management, 60(4), 953964. https://doi.org/https://10.1108/ijlma-03-2017-0026

Palar, A. (2016). The Effect of Work Motivation and Jobsatisfaction on Employee Performance at Banksulutgo Tomohon. Jurnal Berkala IImiah Efisiensi, 16(3), 562572.

Riskayani, N. (2017). Pengaruh Motivasi terhadap Kinerja Karyawan yang Dimoderasi Kompensasi dan Dimediasi Kepuasan Kerja. Jurnal Riset Sains Dan Manajemen, 1(2), 151-164. https://doi.org/10.5281/zenodo.1174938

Robbins, Stephen \& Coutler, M. (2013). Manajemen (Edisi 10.). Jakarta: Erlangga.

Sandhu, M, A., Ali, W., Iqbal, J., \& Tufail, S, M. (2017). Effect of Employee Motivation on Employee Performance. Journal of Business and Social Review in Emerging Economies, 3(1), 91-102. https://doi.org/https://10.26710/jbsee.v3i1.182

Supriatna, S., Mulyana, M., \& Utari, W. D. (2021). Evaluasi Kelompok Referensi Yang Mempengaruhi Keputusan Pembelian Konsumen Foresthree Coffee. Jurnal IImiah Pariwisata Kesatuan, 2(2), 1-10.

Sutrisno, E. (2016). Manajemen Sumber Daya Manusia. Jakarta: Penerbit Kencana.

Wibowo. (2015). Perilaku dalam Organisasi (Edisi Kedu). Jakarta: PT Raja Grafindo Persada.

\section{JAS-PT}

JURNAL ANALISIS SISTEM PENDIDIKAN TINGG

ISSN $2580-5339$

eISSN $2620-5718$

Volume 5

Nomor 1

JULI 2021

Hal 9 - 16

DOSEN INDONESIA SEMESTA 